\title{
Population structure and effects of inbreeding on milk yield and quality of Murrah buffaloes
}

\author{
M. L. Santana Jr., ${ }^{*}$ R. R. Aspilcueta-Borquis, $†$ A. B. Bignardi, $\nmid$ L. G. Albuquerque, $\nmid$ and H. Tonhati $\dagger^{1}$ \\ *Instituto de Ciências Agrárias e Tecnológicas, Universidade Federal de Mato Grosso, MT-270, Km 06, CEP 78735-901, \\ Campus Universitário de Rondonópolis, MT, Brazil \\ †Faculdade de Ciências Agrárias e Veterinárias, Universidade Estadual Paulista Júlio de Mesquita Filho, CEP 14884-900, Jaboticabal, SP, Brazil
}

\begin{abstract}
To provide data for conservation, selection, and expansion programs of buffalo herds, this study evaluated the history of a population of Murrah buffaloes based on population structure and the effect of inbreeding on accumulated 305-d milk yield (MY), fat yield (FY), protein yield (PY), mozzarella production (MProd), and somatic cell score (SCS). The usefulness of including the individual inbreeding coefficient $(F)$ or individual increase in inbreeding coefficient $(\Delta F)$ in the model to describe inbreeding depression was evaluated. Pedigree information from 8,054 animals born between 1976 and 2008 and 4,497 lactation records obtained from 12 herds were used. The realized effective population size was $40.10 \pm 1.27$, and the mean $F$ of the entire population was $2.14 \%$. The ratio between the number of founders and ancestors demonstrated the existence of a bottleneck in the pedigree of this population, which may contribute to a reduction of genetic diversity. The effect of $F$ on MY, FY, PY, MProd, and SCS was -1.005 $\mathrm{kg},-0.299 \mathrm{~kg},-0.246 \mathrm{~kg},-1.201 \mathrm{~kg}$, and -0.002 units, and the effect of $\Delta F$ transformed to equivalent $F(\%)$ for a mean of 2.57 equivalent generations was -4.287 $\mathrm{kg},-0.581 \mathrm{~kg},-0.383 \mathrm{~kg},-2.001 \mathrm{~kg}$, and -0.007 units, respectively. The inbreeding depression observed may have important economic repercussions for production systems. The $\Delta F$ can be considered the better of the two indicators of inbreeding depression due to its properties that prevent underestimation of this effect. A designed mating system to avoid inbreeding may be applied to this population to maintain genetic diversity. Key words: buffalo, inbreeding depression, milk yield, somatic cell
\end{abstract}

\section{INTRODUCTION}

Buffaloes (Bubalus bubalis) account for only about $10 \%$ of the effective world cattle population but are of marked socioeconomic importance in view of their

Received March 21, 2011.

Accepted June 6, 2011.

${ }^{1}$ Corresponding author: tonhati@fcav.unesp.br strong presence in Asian countries where they have important functions as working animals; for example, in rice production (FAO, 2007). Particularly in India, Pakistan, and Egypt, these animals are responsible for most of the milk produced and consumed by the local populations (Nanda and Nakao, 2003). Buffaloes play an important role in Italy, where their milk is used for the production of the traditional mozzarella cheese. Brazil has the largest buffalo population in America (1.2 million animals). The Brazilian buffalo herd consists of animals of the Jafarabadi and Murrah breeds originating in India and animals of the Mediterranean breed originating in Italy. The main and last entry of Murrah animals in Brazil occurred in 1962, when 5 males and 12 females were imported. Only a few animals gave origin to the animals that today comprise the national herd, suggesting that the effective population size may be small and the level of inbreeding high.

According to Gutiérrez et al. (2008), the evaluation of population structure by pedigree analysis is an important tool to describe genetic variability and its evolution over generations. Falconer and Mackay (1996) suggested that inbreeding should be controlled in a population because of its unfavorable effect on economically important traits (inbreeding depression) and on additive genetic variance.

Various investigators have studied inbreeding depression, with the inbreeding coefficient of the animal $(\boldsymbol{F})$ being included as a covariate in the genetic evaluation model in most cases. However, because $F$ is not linearly dependent on pedigree knowledge of the animal, González-Recio et al. (2007) proposed the use of the individual increase in inbreeding coefficient $(\boldsymbol{\Delta} \boldsymbol{F})$ instead of $F$ in the model to describe the effect of inbreeding depression considering pedigree knowledge over generations. The use of $\Delta F$ corrects the cumulative inbreeding coefficient $F$ with regard to the pedigree depth of the animal. In case of equally complete generations of animals under analysis, this correction will have no effect.

Milk production has increased over the last years in southeastern Brazil due to the better prices paid by dairy industries specializing in the production of 
mozzarella. Buffalo milk has excellent physical and chemical qualities because of the high concentration of its components (Tonhati et al., 2000; Rosati and Van Vleck, 2002; Aspilcueta-Borquis et al., 2010). In view of the importance of buffaloes for global agriculture in general, and for the southeast region of Brazil in particular, the objective of the present study was to investigate the population structure and effect of inbreeding on milk production and quality traits of buffaloes.

\section{MATERIALS AND METHODS}

\section{Data}

Pedigree and production data were obtained from the Buffalo Milk Test Program developed by the Animal Science Department of São Paulo State University (FCAV, Jaboticabal, São Paulo, Brazil). The complete pedigree included 8,054 animals born between 1976 and 2008.

Most herds considered in this study use fixed-time AI in 2 cycles. The cows that remained nonpregnant after 2 cycles were exposed to natural mating at a rate of 1 bull to 30 cows. In general, the bulls used in natural service were unrelated. Animals were raised on pasture with feed supplementation during the dry period from April to September. Machine milking was performed twice daily and milk yield and its components were measured monthly.

\section{Population Structure and Inbreeding}

Population structures were analyzed in terms of pedigree completeness level $(\boldsymbol{I})$, individual inbreeding coefficient $(F)$, average relatedness (AR), generation interval, individual increase in inbreeding coefficient $(\Delta F)$, "realized" effective population size $(\overline{N e})$, and effective number of founders $\left(f_{e}\right)$, ancestors $\left(f_{a}\right)$, and founder genome equivalents $\left(\boldsymbol{f}_{g}\right)$. All parameters were computed for the animals belonging to the reference population, defined as animals born in the last generation interval $(\mathrm{n}=6,300)$. The software programs ENDOG version 4.6 (Gutiérrez and Goyache, 2005) and Poprep (Groeneveld et al., 2009) were used for pedigree analysis.

The following formulas were used to compute pedigree completeness (MacCluer et al., 1983):

$$
\begin{gathered}
I_{d}=\frac{4 I_{d_{p a t}} I_{d_{\text {mat }}}}{I_{d_{p a t}}+I_{d_{\text {mat }}}} \text { and } \\
I_{d_{k}}=\frac{1}{d} \sum_{i=1}^{d} a_{i},
\end{gathered}
$$

where $k$ corresponds to the paternal (pat) or maternal (mat) line of an individual, $a_{i}$ is the proportion of known ancestors in generation $i$, and $d$ is the number of generations considered in the calculation of pedigree completeness. The level of pedigree completeness ranged from 0 to $100 \%$.

The $F$ was calculated as proposed by Meuwissen and Luo (1992). The AR was calculated for each individual and is defined as the probability that an allele randomly chosen from the whole population in the pedigree belongs to a given animal. The AR was then interpreted as the representation of the animal in the whole pedigree regardless of knowledge of its own pedigree. The generation interval was defined as average age of parents at the birth of their progeny that were subsequently kept for reproduction.

The $\Delta F$ was calculated as described by Falconer and Mackay (1996) and modified by González-Recio et al. (2007) and Gutiérrez et al. (2009):

$$
\Delta F=1-\sqrt[t-1]{1-F},
$$

where $F$ is the inbreeding coefficient of individual and $t$ is the "equivalent complete generations" for this individual (Maignel et al., 1996; Boichard et al., 1997). A better expression for $\Delta F$ would be " $F$ corrected for equivalent complete generations." The expression relating inbreeding in generation $t$ to the inbreeding rate proposed by Gutiérrez et al. (2009) is

$$
F_{t}=1-(1-\Delta F)^{t-1}
$$

The effective population size $\overline{N e}$ (Gutiérrez et al., 2008), called realized effective size by Cervantes et al. (2008), was estimated from $\overline{\Delta F}$, which can be computed by averaging the $\Delta F$ of $n$ individuals included in a given reference subpopulation, as $\overline{N e}=1 / 2 \overline{\Delta F}$. The standard error of $\overline{\mathrm{Ne}}$ was calculated as described by Gutiérrez et al. (2008).

The parameters $f_{e}$ and $f_{a}$ were obtained to evaluate the concentration of the origin of both animals and genes. Parameter $f_{e}$ is defined as the number of equally contributing founders that would be expected to produce the same genetic diversity as observed in the population under study (Lacy, 1989). When founders contribute to the reference population more equally, the effective number of founders is higher. This parameter was calculated as

$$
f_{e}=1 /\left(\sum_{k=1}^{f} q_{k}^{2}\right)
$$


Table 1. Description of the data set

\begin{tabular}{|c|c|c|c|c|c|}
\hline Item & \multicolumn{5}{|c|}{ Trait $^{1}$} \\
\hline No. of records & 4,497 & 2,059 & 2,059 & 2,059 & 1,345 \\
\hline $\mathrm{SD}$ & 719.49 & 51.56 & 31.16 & 162.83 & 1.35 \\
\hline Average $F^{2} \%$ & 1.59 & 1.50 & 1.50 & 1.50 & 1.24 \\
\hline Range of $F, 2 \%$ & $0.00-31.25$ & $0.00-30.07$ & $0.00-30.07$ & $0.00-30.07$ & $0.00-30.07$ \\
\hline
\end{tabular}

${ }^{1} \mathrm{MY}=305$-d milk yield; $\mathrm{FY}=$ fat yield; $\mathrm{PY}=$ protein yield; MProd $=$ mozzarella production.

${ }^{2}$ Considering all cows with data; $F=$ individual inbreeding coefficient; $\Delta F=$ individual increase in inbreeding coefficient.

where $q_{k}$ is the probability of gene origin of ancestor $k$. The $f_{a}$ is the minimum number of ancestors, not necessarily founders, explaining the complete genetic diversity of a population. This parameter complements the information offered by the effective number of founders by accounting for the losses of genetic variability caused by the unbalanced use of reproductive individuals producing bottlenecks. This parameter was calculated as

$$
f_{a}=1 /\left(\sum_{j=1}^{a} q_{j}^{2}\right),
$$

where $q_{j}$ is the marginal contribution of ancestor $j$, which is the genetic contribution made by an ancestor that is not explained by other ancestors chosen before. The $f_{q}$ can be defined as the number of founders that would be expected to produce the same genetic diversity as observed in the population under study if the founders were equally represented and no loss of alleles occurred (Ballou and Lacy, 1995). Following Caballero and Toro (2000), parameter $f_{g}$ was obtained by the inverse of twice the average co-ancestry of the individuals included in a predefined reference population.

\section{Inbreeding Depression}

In total, 4,497 lactation records from 1,778 Murrah buffaloes born between 1987 and 2004, with at least 2 equivalent generations of known pedigree and belonging to 12 herds, were used to analyze the effect of inbreeding (Table 1). In this case, the complete relationship matrix included 2,590 animals. The mean lactation length and age at first calving were $270.35 \pm 58.55 \mathrm{~d}$ and $35.96 \pm 4.63 \mathrm{mo}$, respectively. The following traits were studied: cumulative 305-d milk yield (MY), fat yield $(\mathbf{F Y})$, protein yield $(\mathbf{P Y})$, mozzarella production (MProd), and SCC. The SCC values were obtained by averaging monthly test-day records per lactation; SCC was transformed into SCS as described by Dabdoub and Shook (1984): SCS $=\left[\log _{2}(\mathrm{SCC} / 100,000)\right]+3$.
For all traits, lactation records were not adjusted for DIM, and lactations with a length above $305 \mathrm{~d}$ were truncated at this point, as suggested by Tonhati et al. (2008). As proposed by Altiero et al. (1989), MProd was based on MY, average milk fat percentage $(\% \mathrm{~F})$, and average milk protein percentage $(\% \mathrm{P})$, using the formula adopted for genetic evaluation programs in Italy. In the present study, MProd accumulated at 305 $\mathrm{d}$ was used because it is based on MY at $305 \mathrm{~d}$ :

$$
\begin{gathered}
\text { MProd }(\mathrm{kg})=\mathrm{MY} \times\{[(3.5 \times \% \mathrm{P}) \\
+(1.23 \times \% \mathrm{~F})-0.88] / 100\} .
\end{gathered}
$$

Lactations $<90 \mathrm{~d}$ were deleted. The first test-day milk record was measured between d 5 and 75 after calving. Contemporary groups were defined as animals that calved in the same herd, year and season (season 1 from April to September and season 2 from October to March). Contemporary groups with fewer than 4 lactations (animals) and animals with records for each trait that were $\pm 3.0 \mathrm{SD}$ of the $\mathrm{CG}$ average were excluded from the analyses.

Multi-trait analysis was performed using a repeatability animal model and the AIREMLF90 program (Misztal et al., 2002). Two different models were run: model 1 included the fixed effects of CG, number of milkings (1 or 2), and lactation number (from 1 to 7 ), and the covariates age at calving (linear and quadratic) and $F$ (linear). Additive genetic and permanent environmental effects were included as random effects. Model 2 was similar to model 1, but included $\Delta F$ instead of $F$ as a linear covariate (Table 1).

\section{RESULTS AND DISCUSSION}

\section{Population Structure}

For the population studied, the pedigree knowledge of animals in each generation has increased over the years (Figure 1). According to Gutiérrez et al. (2008), 


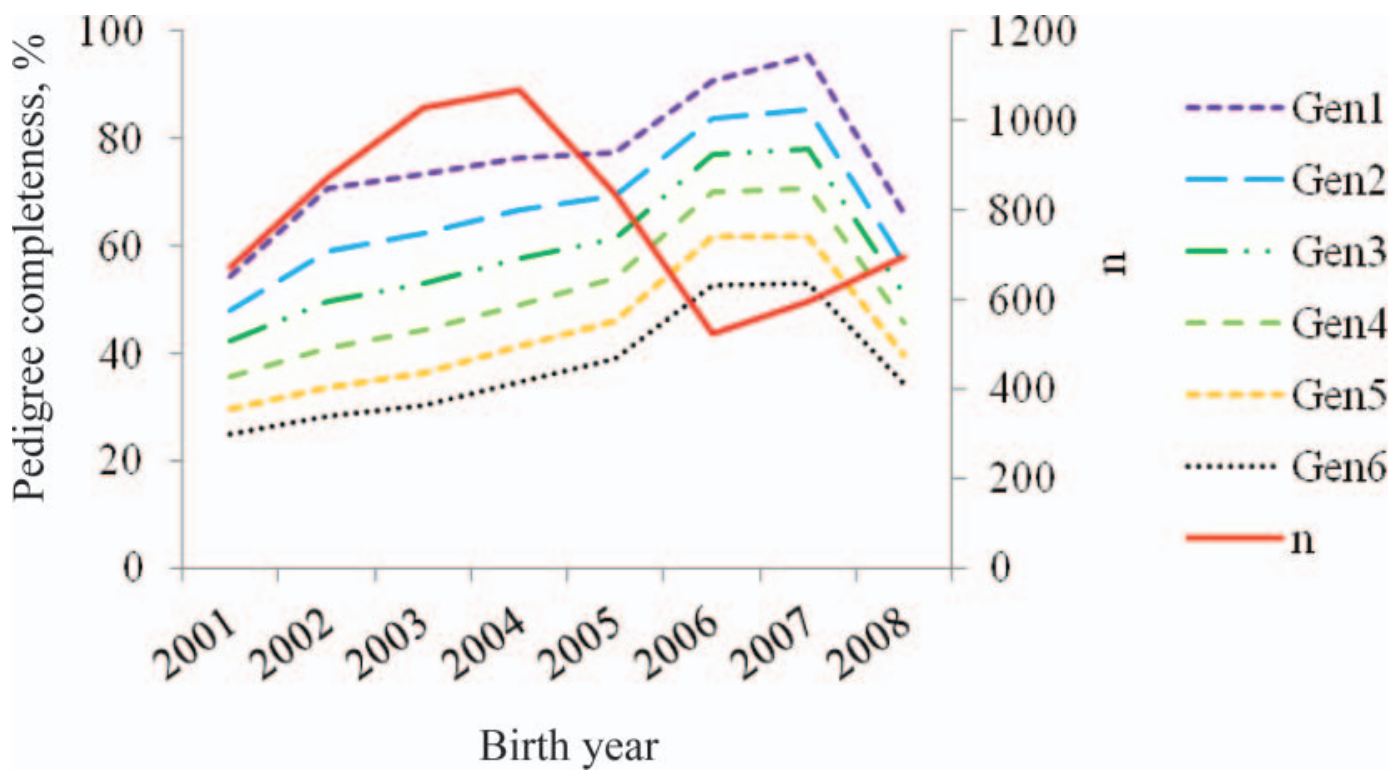

Figure 1. Number of animals (n) and average pedigree completeness (\%) for 1 to 6 generations (Gen) according to year of birth (2001 to 2008). Color version available in the online PDF.

the pedigree information of animals in a population is important because various population parameters such as $F$ and AR depend on it. The average pedigree completeness for animals born within the last $10 \mathrm{yr}$ was as follows: 1 generation $=76.2 \% ; 2$ generations $=66.3 \% ; 3$ generations $=57.8 \% ; 4$ generations $=49.8 \% ; 5$ generations $=42.1 \%$; and 6 generations $=35.6 \%$.

The mean $F$ and AR of the whole population studied were 2.14 and $3.58 \%$, respectively. Gutiérrez et al. (2003) reported a mean $F$ of 0.48 to $3.13 \%$ for 8 Spanish beef cattle breeds. Carneiro et al. (2009) found a mean $F$ of $7.37 \%$ in the sixth generation of an Indubrasil cattle population from northeastern Brazil. A mean $F$ of $6.75 \%$ was reported by Carolino and Gama (2008) for Alentejana cattle. Marcondes et al. (2010) observed a mean $F$ of $0.5 \%$ for buffaloes from northern Brazil, but the number of animals studied was small (776). Compared with these results, the mean $F$ obtained in the present study was low. The AR was higher than the estimates reported by Peixoto et al. (2010) in a study of a subpopulation of the Guzerat cattle breed (1.1\%). This parameter has not been previously reported for buffaloes. The AR estimate obtained for the present population indicates an expected increase in the number of matings between related individuals in the near future if no appropriate measures are taken.

The percentage of inbred animals, sires, and dams, and equivalent generations of animals born in the last 15 yr are shown in Figure 2. Similarly, Gutiérrez et al. (2003) reported that percentage of inbred animals in 8 Spanish beef cattle breeds ranged from 1.73 to $48.3 \%$.
In contrast, Panetto et al. (2010), in a study on Guzerat cattle, observed that more than $91 \%$ of all animals were inbred. In the present study, the mean percentage of inbred sires and dams was high (about 50\%), a fact that may rapidly lead to an increase of the average level of $F$ in the population if no consistent mating system is designed to avoid the inbreeding. Abrupt changes were observed in percentage of inbred sires and dams between 2005 and 2008. This could be due to the changes in the number of equivalent generations.

The mean generation interval found in the present study was $6.89 \mathrm{yr}$ (Table 2). This interval is shorter than that reported for Zebu cattle raised under Brazilian conditions. Faria et al. (2009) observed a generation interval of about $8 \mathrm{yr}$ for the Nellore, Gyr, and Guzerat cattle breeds. Peixoto et al. (2010) reported a generation interval of $7.48 \mathrm{yr}$ for a subpopulation of the Guzerat breed selected for milk yield. In a study on polled Nellore animals, the generation interval was 8.3 yr (Malhado et al., 2008a). The generation interval obtained for the present population was also shorter than that reported by Malhado et al. (2008b) for Mediterranean water buffaloes (11.3 yr). The mean generation interval is an important parameter in genetic improvement because it directly influences the annual genetic gain in selected traits. According to Table 3, several sires and dams more than 13 yr old are still being used in the population, which may represent an increase in the genetic lag.

The $\overline{N e}$ for this population was $40.10(\mathrm{SE}=1.27)$, a value considered to be low. The FAO (2007) recom- 
Table 2. Number of animals (n), generation interval (GI), and standard deviation by selection path

\begin{tabular}{lrcc}
$\begin{array}{l}\text { Selection } \\
\text { path }\end{array}$ & \multicolumn{1}{c}{$\mathrm{n}$} & $\mathrm{GI}$ & $\mathrm{SD}$ \\
\hline Sire-son & 93 & 7.38 & 3.64 \\
Sire-daughter & 1,814 & 7.42 & 3.27 \\
Dam-son & 100 & 6.60 & 3.44 \\
Dam-daughter & 2,195 & 6.44 & 3.69 \\
Total & 4,202 & 6.89 & 3.54 \\
\hline
\end{tabular}

mends an effective population size of more than 50 animals for genetic variability to be preservable. According to the FAO (1992), the loss of genetic diversity over 10 generations is approximately $18,10,4,1.6$, and $0.8 \%$ when the effective population size is $25,50,125,250$, and 500, respectively. Therefore, detailed knowledge of the pedigree of each animal and the monitoring of the effective size are recommended actions. In addition, a mating scheme to avoid inbreeding should be applied to this population to maintain genetic diversity.

Parameters $f_{e}, f_{a}$, and $f_{g}$ were 55,35 and 28 , respectively. These values were low compared with the number of animals born in the last generation interval $(6,300$ animals) and number of founders (2,374 animals). The $f_{a}: f_{e}(0.63)$ and $f_{g}: f_{e}(0.51)$ ratios indicate the existence of bottlenecks in the pedigree of the population. This finding suggests an unbalanced contribution of animals, a fact that may reduce genetic diversity.

In the study of Malhado et al. (2008b) involving a Brazilian water buffalo population of Mediterranean origin, the expected inbreeding due to the unbalanced use of founders was $0.06 \%$ and the number of ancestors explaining $50 \%$ of the genetic diversity of the population was 414 animals. The respective values found in the present study were $0.79 \%$ and 19 animals, indicating the existence of deficiencies in the structure of this population; these included failures in the mating policy, intensive use of certain individuals as breeding animals, and reduced effective population size, among other reasons.

Investigators studying different species found that a small number of animals may contribute largely to

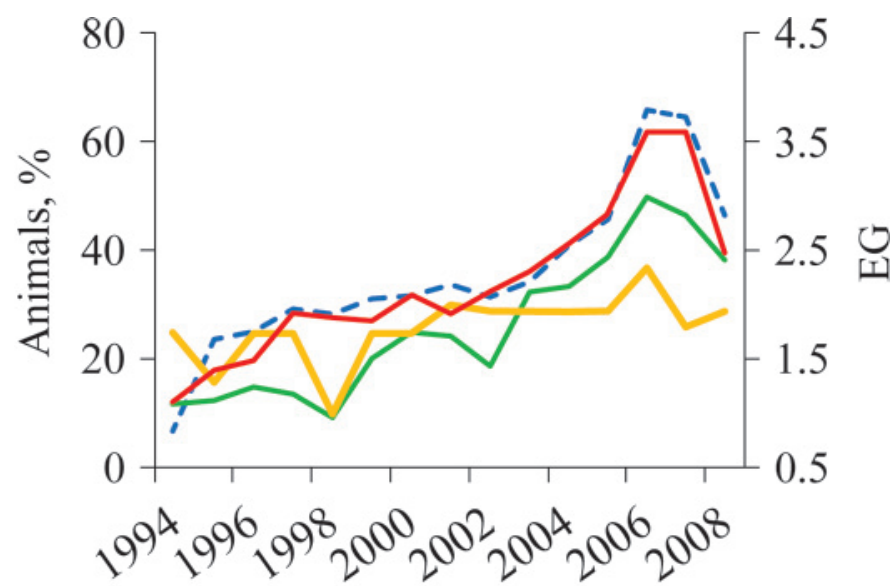

Birth year

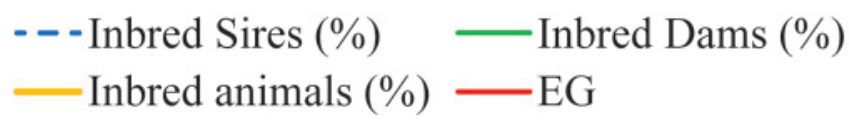

Figure 2. Percentage of inbred animals, sires, and dams in the entire population and number of equivalent generations (EG) of animals born in the last $15 \mathrm{yr}$. Color version available in the online PDF.

their respective populations: for example, Sørensen et al. (2005) reported that 193, 73, and 126 ancestors explain $90 \%$ of the gene pool in Holstein, Jersey, and Red Danish cattle, respectively. Faria et al. (2009) found 56,37 , and 41 ancestors to explain $50 \%$ of the gene pool in Nellore, Gyr, and Guzerat cattle, respectively. Similarly, Voges and Distl (2009) reported 56, 36, and 15 ancestors to explain $90 \%$ of gene pool in Bavarian, Hanoverian, and Tyrolean hounds. Thus, this seems to be a common problem in some breeds of the main domestic species, which may become worse in the future.

\section{Inbreeding Depression}

Table 4 shows the solutions of $F$ and $\Delta F$ for the quantification of inbreeding depression on economically important traits in the Murrah buffalo population stud-

Table 3. Age distribution of sires and dams by birth year of their offspring

\begin{tabular}{|c|c|c|c|c|c|c|c|c|c|c|c|c|}
\hline \multirow[b]{2}{*}{ Year } & \multicolumn{5}{|c|}{ Age $(y r)$ of sires } & \multirow[b]{2}{*}{ Total } & \multicolumn{5}{|c|}{ Age (yr) of dams } & \multirow[b]{2}{*}{ Total } \\
\hline & 2 to 4 & 5 to 7 & 8 to 10 & 11 to 13 & $>13$ & & 2 to 4 & 5 to 7 & 8 to 10 & 11 to 13 & $>13$ & \\
\hline 2001 & 9 & 4 & 6 & 2 & 1 & 22 & 260 & 142 & 58 & 31 & 25 & 516 \\
\hline 2002 & 7 & 3 & 5 & 1 & 3 & 19 & 347 & 179 & 79 & 49 & 34 & 688 \\
\hline 2003 & 12 & 9 & 3 & 2 & 2 & 28 & 366 & 274 & 98 & 52 & 48 & 838 \\
\hline 2004 & 15 & 10 & 3 & 1 & 2 & 31 & 386 & 280 & 135 & 61 & 46 & 908 \\
\hline 2005 & 14 & 7 & 3 & 1 & 2 & 27 & 352 & 201 & 111 & 42 & 29 & 735 \\
\hline 2006 & 10 & 5 & 4 & 2 & 1 & 22 & 283 & 122 & 65 & 16 & 8 & 494 \\
\hline 2007 & 11 & 8 & 0 & 2 & 1 & 22 & 263 & 186 & 84 & 21 & 9 & 563 \\
\hline 2008 & 8 & 9 & 1 & 3 & 1 & 22 & 270 & 171 & 52 & 26 & 5 & 524 \\
\hline
\end{tabular}


Table 4. Model solutions for the effect of individual inbreeding coefficient $(F)$ and individual increase in inbreeding coefficient $(\Delta F)$ converted to inbreeding coefficient $F(\% \pm \mathrm{SE})$ for 2.57 equivalent generations on 305-d milk yield (MY), fat yield (FY), protein yield (PY), mozzarella production (MProd), and SCS

\begin{tabular}{lll}
\hline & & \multicolumn{1}{c}{$\Delta F$ converted } \\
Item & \multicolumn{1}{c}{ to $F(\%)$}
\end{tabular}

ied. The effect of inbreeding was significant for most of the traits, except PY (model with F) and SCS (both models).

The $\Delta F$ is considered an alternative measure of inbreeding adjusted for the pedigree knowledge of each animal in the population. According to González-Recio et al. (2007), this coefficient corrects the cumulative inbreeding coefficient for the number of generations of each animal. Using $\Delta F, 2$ animals with the same $F$ but with different amounts of pedigree information are considered to be different. Panetto et al. (2010) reported that another reason to choose $\Delta F$ instead of $F$ is that the regular inbreeding coefficients generally increase over years and might be confused with the effects accounting for time such as $\mathrm{CG}$, whereas $\Delta F$ does not increase over years.

Initial model solutions for $\Delta F$ on $\mathrm{MY}, \mathrm{FY}, \mathrm{PY}$, MProd, and SCS were $-6.689,-0.907,-0.599,-3.123$, and -0.011 , respectively. To illustrate and facilitate the interpretation of inbreeding when the model includes $\Delta F$ as the covariate, this parameter can be transformed into the inbreeding coefficient for an animal with an average depth of pedigree using equation [2]. Transformed model solutions for $\Delta F$ on MY, FY, PY, MProd, and SCS to equivalent $F(\%)$ for a mean of 2.57 equivalent generations were $-4.287,-0.581,-0.383,-2.001$, and -0.007 , respectively (Table 4 ). In other words, a $\Delta F$ of $1 \%$, corresponding to an inbreeding coefficient of $1.56 \%$ for the mean of equivalent generations of the data set used (2.57), reduces MY, FY, PY, MProd, and SCS by the amount shown in Table 4 . On the basis of these results, an animal with an inbreeding coefficient of $25 \%$ would produce, on average, $107.175 \mathrm{~kg}, 14.525$ $\mathrm{kg}, 9.575 \mathrm{~kg}, 52.005 \mathrm{~kg}$, and 0.175 units less of MY, FY, PY, MProd, and SCS, respectively, than a noninbred animal. Using the $F$ approach, these estimates of inbreeding depression would be $25.127 \mathrm{~kg}, 7.475 \mathrm{~kg}, 6.150$ $\mathrm{kg}, 30.025 \mathrm{~kg}$, and 0.05 units, respectively. Therefore, the model that included $\Delta F$ provided larger and more significant estimates of inbreeding depression than the model incorporating $F$. The $\Delta F$ can be considered the better indicator of inbreeding depression due to its properties that prevent the underestimation of this effect (González-Recio et al., 2007; Panetto et al., 2010).

Inbreeding depression calculated for the traits studied here may have important economic implications for the buffalo production system. Studying a herd of Egyptian buffaloes, Khattab and Kawthar (2007) observed that 305-d milk production is lower in inbred animals than in noninbred animals. Mirhabibi et al. (2007), studying buffaloes from South Iran, found that the group of inbred animals produced, on average, 32 $\mathrm{kg}$ less milk during lactation and $0.06 \%$ less fat than noninbred animals. However, Vasconcellos and Tonhati (1998) reported no effect of inbreeding on total milk yield during lactation of Murrah buffaloes in Brazil, although only one herd was analyzed in that study. Inbreeding depression has also been reported for dairy cattle. Miglior et al. (1992) found significant inbreeding depression on MY, FY, and milk fat percentage in Jersey animals. Studying Holstein cattle in Iran, Rokouei et al. (2010) observed a significant reduction of MY, FY, and PY per $1 \%$ increase in inbreeding. Similarly, Croquet et al. (2007) reported a reduction of MY, FY, and PY with increasing inbreeding coefficient in Walloon Holstein cows.

To our knowledge, no studies have investigated the effect of inbreeding on MProd and SCS in buffaloes. As can be seen in Table 4, a significant reduction was observed in MProd $(P<0.05)$, which is calculated as a function of the percentage of fat and protein, indicating a probable decrease in the concentration of these components in milk. Inbreeding had no significant effect on SCS in this study. According to the literature, no consensus exists regarding the effect of inbreeding on SCS in dairy cattle. Thompson et al. (2000) reported no significant effects of inbreeding on SCS, although they observed losses in fat, protein, and milk production. Similarly, Smith et al. (1998) reported that inbreeding depression on first-lactation SCS was not significant. On the other hand, Miglior et al. (1992) found an increase of 0.012 units in SCS per 1\% increase in inbreeding, in agreement with the findings of Rokouei et al. (2010).

Estimates of inbreeding depression using $\Delta F$ were higher than those obtained from the $F$ approach because pedigrees, in the present study, were not very deep and complete. In case of complete pedigrees, this might not be true.

\section{Genetic Parameters and Inbreeding}

No differences were observed in the estimates of covariance components, heritability, and correlations between traits obtained by the 2 models $(F$ and $\Delta F$ ). Table 5 shows the estimates of genetic parameters for 
Table 5. Estimates of heritability (diagonal), genetic correlation (above diagonal), and temporary environmental correlation (below diagonal) for milk yield (MY), fat yield (FY), protein yield (PY), mozzarella production (MProd), and SCS

\begin{tabular}{lrrrrr}
\hline Trait & \multicolumn{1}{c}{ MY } & \multicolumn{1}{c}{ FY } & \multicolumn{1}{c}{ PY } & MProd & \multicolumn{1}{c}{ SCS } \\
\hline MY & $0.23 \pm 0.03$ & $0.77 \pm 0.08$ & $0.95 \pm 0.01$ & $0.97 \pm 0.02$ & $-0.05 \pm 0.17$ \\
FY & $0.90 \pm 0.00$ & $0.20 \pm 0.04$ & $0.81 \pm 0.07$ & $0.72 \pm 0.06$ & $-0.03 \pm 0.18$ \\
PY & $0.94 \pm 0.00$ & $0.89 \pm 0.01$ & $0.21 \pm 0.04$ & $0.89 \pm 0.03$ & $-0.09 \pm 0.16$ \\
MProd & $0.96 \pm 0.01$ & $0.81 \pm 0.01$ & $0.87 \pm 0.02$ & $0.21 \pm 0.08$ & $-0.08 \pm 0.19$ \\
SCS & $-0.24 \pm 0.05$ & $-0.15 \pm 0.05$ & $-0.23 \pm 0.04$ & $0.26 \pm 0.08$ & $0.24 \pm 0.05$ \\
\hline
\end{tabular}

all traits obtained from the model including $F$. The Pearson correlations between estimated breeding values obtained from the 2 models were 0.99 . When 5,10 , or $20 \%$ of the best bulls were selected for each trait using the 2 models, the percentage of bulls selected in common was $100 \%$. Therefore, no significant changes in the ranking of animals are expected between results from fitting $F$ or $\Delta F$, in agreement with the findings of González-Recio et al. (2007) for the Spanish Holstein population.

\section{CONCLUSIONS}

Problems exist in the structure of the Murrah buffalo population in southeastern Brazil, in the form of bottlenecks and small effective size. Inbreeding generally had a negative effect on milk production and quality traits. The effect observed may have important economic implications for production systems. A mating system designed to avoid an increase of inbreeding should be applied to this population to maintain genetic diversity.

\section{REFERENCES}

Altiero, V., L. Moio, and F. Addeo. 1989. Previsione della resa in "mozzarella" sulla base del contenuto in graso e proteine del latte di bufala. Sci. Tecn. Latt. Cas. 40:425-433.

Aspilcueta-Borquis, R. R., R. Di Palo, F. R. Araujo Neto, F. Baldi, G. M. F. de Camargo, L. G. de Albuquerque, L. Zicarelli, and H. Tonhati. 2010. Genetic parameter estimates for buffalo milk yield, milk quality and mozzarella production and Bayesian inference analysis of their relationships. Genet. Mol. Res. 9:1636-1644.

Ballou, J. D., and R. C. Lacy. 1995. Identifying genetically important individuals for management of genetic variation in pedigreed populations. Pages 76-111 in Population Management for Survival and Recovery. J. D. Ballou, M. Gilpin, and T. J. Foose, ed. Columbia University Press, New York, NY.

Boichard, D., L. Maignel, and E. Verrier. 1997. The value of using probabilities of gene origin to measure genetic variability in a population. Genet. Sel. Evol. 29:5-23.

Caballero, A., and M. A. Toro. 2000. Interrelations between effective population size and other pedigree tools for the management of conserved populations. Genet. Res. 75:331-343.

Carneiro, P. L. S., C. H. M. Malhado, R. Martins Filho, A. P. S. Carneiro, F. F. Silva, and R. A. Torres. 2009. The Indubrasil breed in the Brazilian Northeast: Breeding and population structure. R. Bras. Zootec. 38:2327-2334

Carolino, N., and L. T. Gama. 2008. Inbreeding depression on beef cattle traits: Estimates, linearity of effects and heterogeneity among sire-families. Genet. Sel. Evol. 40:511-527.
Cervantes, I., F. Goyache, A. Molina, M. Valera, and J. P. Gutiérrez. 2008. Application of individual increase in inbreeding to estimate realized effective sizes from real pedigrees. J. Anim. Breed. Genet. 125:301-310.

Croquet, C., P. Mayeres, A. Gillon, H. Hammami, H. Soyeurt, S. Vanderick, and N. Gengler. 2007. Linear and curvilinear effects of inbreeding on production traits for Walloon Holstein Cows. J. Dairy Sci. 90:465-471.

Dabdoub, S. A. M., and G. E. Shook. 1984. Phenotypic relations among milk yield, somatic count cells, and mastitis. J. Dairy Sci. 67:163-164.

Falconer, D. S., and T. F. C. Mackay. 1996. Introduction to Quantitative Genetics, 4th ed. Longman Group Ltd., Harlow, UK.

FAO. 1992. Monitoring animal genetic resources and criteria for prioritization of breeds. The Management of Global Animal Genetic Resources: Proceedings of an FAO Expert Consultation, no. 104. J. Hodges, ed. FAO, Rome, Italy.

FAO. 2007. The State of the World's Animal Genetic Resources for Food and Agriculture. B. Rischkowsky and D. Pilling, ed. FAO, Rome, Italy.

Faria, F. J. C., A. E. V. Filho, F. E. Madalena, and L. A. Josahkian. 2009. Pedigree analysis in the Brazilian Zebu breeds. J. Anim. Breed. Genet. 126:148-153.

González-Recio, O., E. López de Maturana, and J. P. Gutiérrez. 2007. Inbreeding depression on female fertility and calving ease in Spanish dairy cattle. J. Dairy Sci. 90:5744-5752.

Groeneveld, E., B. d. Westhuizen, A. Maiwashe, F. Voordewind, and J. B. S. Ferraz. 2009. POPREP: A generic report for population management. Genet. Mol. Res. 8:1158-1178.

Gutiérrez, J. P., J. Altarriba, C. Díaz, R. Quintanilla, J. Cañón, and J. Piedrafita. 2003. Pedigree analysis of eight Spanish beef cattle breeds. Genet. Sel. Evol. 35:43-63.

Gutiérrez, J. P., I. Cervantes, and F. Goyache. 2009. Improving the estimation of realized effective population sizes in farm animals. J. Anim. Breed. Genet. 126:327-332.

Gutiérrez, J. P., I. Cervantes, A. Molina, M. Valera, and F. Goyache. 2008. Individual increase in inbreeding allows estimating realised effective sizes from pedigrees. Genet. Sel. Evol. 40:359-378.

Gutiérrez, J. P., and F. Goyache. 2005. A note on ENDOG: A computer program for analysing pedigree information. J. Anim. Breed. Genet. 122:172-176.

Khattab, A. S., and A. M. Kawthar. 2007. Inbreeding and its effects on some productive and reproductive traits in a herd of Egyptian buffaloes. Ital. J. Anim. Sci. 6:275-278.

Lacy, R. C. 1989. Analysis of founder representations in pedigrees: Founder equivalents and founder genome equivalents. Zoo Biol. $8: 111-123$.

MacCluer, J. W., A. J. Boyce, B. Dyke, L. R. Weitkamp, D. W. Pfennig, and C. J. Parsons. 1983. Inbreeding and pedigree structure in Standardbred horses. J. Hered. 74:394-399.

Maignel, L., D. Boichard, and E. Verrier. 1996. Genetic variability of French dairy breeds estimated from pedigree information. Interbull Bull. 14:49-54.

Malhado, C. H. M., P. L. S. Carneiro, D. G. Pereira, and R. Martins Filho. 2008a. Genetic progress and population structure in Nellore cattle in Bahia State, Brazil. Pesquisa Agropecu. Bras. 43:1163-1169. 
Malhado, C. H. M., A. A. Ramos, P. L. S. Carneiro, D. M. M. R. Azevedo, R. Martins Filho, and J. C. Souza. 2008b. Improvement and population structure of Mediterranean water buffaloes raised in Brazil. Pesquisa Agropecu. Bras. 43:215-220.

Marcondes, C. R., P. A. Vozzi, B. R. N. Cunha, R. B. Lôbo, C. V. Araújo, and J. R. F. Marques. 2010. Genetic variability in water buffalo from nucleus herd by pedigree analysis. Arq. Bras. Med. Vet. Zootec. 62:706-711.

Meuwissen, T., and Z. Luo. 1992. Computing inbreeding coefficients in large populations. Genet. Sel. Evol. 24:305-313.

Miglior, F., B. Szkotnicki, and E. B. Burnside. 1992. Analysis of levels of inbreeding and inbreeding depression in Jersey cattle. J. Dairy Sci. 75:1112-1118.

Mirhabibi, S., G. Manafiazar, S. Qaravisi, and B. Mahmoodi. 2007. Inbreeding and its effect on some productive traits in buffaloes of South Iran. Ital. J. Anim. Sci. 6:372-374.

Misztal, I., S. Tsuruta, T. Strabel, B. Auvray, T. Druet, and D. W. Lee. 2002. BLUPF90 and related programs (BGF90). Proc. 7th World Congr. Genet. Appl. Livest. Prod., Montpellier, France. Commun. 28-07.

Nanda, A. S., and T. Nakao. 2003. Role of buffalo in the socioeconomic development of rural Asia: Current status and future prospectus. Anim. Sci. J. 74:443-455.

Panetto, J. C. C., J. P. Gutiérrez, J. B. S. Ferraz, D. G. Cunha, and B. L. Golden. 2010. Assessment of inbreeding depression in a Guzerat dairy herd: Effects of individual increase in inbreeding coefficients on production and reproduction. J. Dairy Sci. 93:4902-4912.

Peixoto, M. G. C. D., C. F. Poggian, R. S. Verneque, A. A. Egito, M. R. S. Carvalho, V. M. Penna, J. A. G. Bergmann, L. F. Viccini, and M. A. Machado. 2010. Genetic basis and inbreeding in the Brazilian Guzerat (Bos indicus) subpopulation selected for milk production. Livest. Sci. 131:168-174.
Rokouei, M., R. Vaez Torshizi, M. Moradi Shahrbabak, M. Sargolzaei, and A. C. Sørensen. 2010. Monitoring inbreeding trends and inbreeding depression for economically important traits of Holstein cattle in Iran. J. Dairy Sci. 93:3294-3302.

Rosati, A., and L. D. Van Vleck. 2002. Estimation of genetic parameters for milk, fat, protein and mozzarella cheese production for the Italian river buffalo Bubalus bubalis population. Livest. Prod. Sci. $74: 185-190$.

Smith, L. A., B. G. Cassell, and R. E. Pearson. 1998. The effects of inbreeding on the lifetime performance of dairy cattle. J. Dairy Sci. 81:2729-2737.

Sørensen, A. C., M. K. Sørensen, and P. Berg. 2005. Inbreeding in Danish dairy cattle breeds. J. Dairy Sci. 88:1865-1872.

Thompson, J. R., R. W. Everett, and C. W. Wolfe. 2000. Effects of inbreeding on production and survival in Jerseys. J. Dairy Sci. 83:2131-2138.

Tonhati, H., M. F. Cerón-Muñoz, J. A. Oliveira, and J. M. C. Duarte. 2000. Genetic parameters of milk production, fat and protein contents in buffalo milk. Braz. J. Anim. Sci. 29:2051-2056.

Tonhati, H., M. F. Cerón-Muñoz, J. A. Oliveira, L. El Faro, A. L. F. Lima, and L. G. Albuquerque. 2008. Test-day milk yield as a selection criterion for dairy buffaloes (Bubalus bubalis Artiodactyla, Bovidae). Genet. Mol. Biol. 31:674-679.

Vasconcellos, B. F., and H. Tonhati. 1998. Inbreeding and its effects on some productive and reproductive traits in a Murrah buffalo herd. J. Anim. Breed. Genet. 115:299-306.

Voges, S., and O. Distl. 2009. Inbreeding trends and pedigree analysis of Bavarian mountain hounds, Hanoverian hounds and Tyrolean hounds. J. Anim. Breed. Genet. 126:357-365. 